\title{
Mn(II) lons Biosorption from Aqueous Solution using Pleurotus Spent Mushroom Compost under Batch Experiment
}

\author{
Ain Nihla Kamarudzaman ${ }^{1,2 a}$, Tay Chia Chay, ${ }^{3, b}$, Amnorzahira Amir ${ }^{1, c}$ \\ and Suhaimi Abdul Talib ${ }^{1, d^{*}}$
}

${ }^{1}$ myBioREC, Faculty of Civil Engineering, Universiti Teknologi MARA, 40450 Shah Alam, Selangor, Malaysia

${ }^{2}$ Pusat Pengajian Kejuruteraan Alam Sekitar, UniMAP, 02600 Arau, Perlis, Malaysia

${ }^{3}$ Faculty of Applied Sciences, Universiti Teknologi MARA, 02600 Arau, Perlis, Malaysia

aainnihla@unimap.edu.my, ${ }^{b}$ taychiay@gmail.com, 'amnorzahira@salam.uitm.edu.my, decsuhaimi@salam.uitm.edu.my

Keywords: Batch Study; Biosorption; Mn(II) ions; Pleurotus spent mushroom compost

\begin{abstract}
The Pleurotus spent mushroom compost was selected as biosorbent to sorption $\mathrm{Mn}$ (II) ions. The $\mathrm{Mn}$ (II) ions biosorption was investigated under batch experiments. The influences of $\mathrm{pH}$, contact time and initial $\mathrm{Mn}$ (II) concentration were also investigated. The optimum $\mathrm{Mn}$ (II) ions biosorption was achieved at $\mathrm{pH} 6,20$ minutes of contact time and $10 \mathrm{mg} / \mathrm{L}$ of initial $\mathrm{Mn}$ (II) concentration using $1.0 \mathrm{~g}$ biosorbent dosage. The $\mathrm{Mn}$ (II) ions biosorption experimental data were best described by the Langmuir isotherm model and pseudo-second order kinetic model. As conclusion, the Pleurotus spent mushroom compost can be used to sorption the $\mathrm{Mn}$ (II) ions from the aqueous solution.
\end{abstract}

\section{Introduction}

Biosorption has been highlighted as a low-cost treatment technology with possibility for biosorbent regeneration, metals recovery and minimizing toxic sludge production [1]. Biosorption is the passive uptake of pollutants by dead or inactive biological materials [2]. The biosorption process mechanisms may involve ion exchange, chemisorption, physical adsorption, complexation, precipitation and chelation [3, 4]. However, the mechanisms responsible for heavy metals uptake will differ according to the functional group of biosorbent. Various agricultural waste as potential biosorbent for heavy metals removal have been investigated including corn chaff [5], tea-waste [6], rice husk [7], peanut shell [8], pre-treated orange peel [9], green tomato husk [10], rubber tree sawdust [11] and neem sawdust [12]. Factors that influence the selection of biosorbent include easily available in large quantities, economical and high uptake capacity [13].

In this study, the Pleurotus spent mushroom compost have been selected as a biosorbent for Mn(II) ions biosorption. It is an abundant agricultural waste material from mushroom farms. In Malaysia, about 24 tons per month of spent mushroom compost are disposed in the municipal solid waste landfill [14]. The aim of the study is to evaluate the performance of $\mathrm{Mn}$ (II) ions biosorption using Pleurotus spent mushroom compost under batch experiments through parameters such as $\mathrm{pH}$, contact time and initial $\mathrm{Mn}$ (II) concentration. The sorption equilibrium of $\mathrm{Mn}$ (II) ions were determined using the Langmuir isotherm model, whereas kinetic data were analysed using a pseudo-second order kinetic model.

\section{Materials and Methods}

Preparation of Biosorbent. The Pleurotus spent mushroom compost sample was obtained from a mushroom production at Muar, Johor state, Malaysia. The sample was sterilised using autoclave (Hirayama, HVE-50) at $121^{\circ} \mathrm{C}$ for 15 minutes and kept in an oven at $60^{\circ} \mathrm{C}$. The dried sample was crushed into powder and sieved to less than $710 \mu \mathrm{m}$ particle size. 
Biosorption Study. About $1.1430 \mathrm{~g}$ of Manganese(II) Nitrate Tetrahydrate $\left(\mathrm{Mn}\left(\mathrm{NO}_{3}\right)_{2} \cdot 4 \mathrm{H}_{2} \mathrm{O}\right)$ was dissolved with $250 \mathrm{~mL}$ ultrapure water to produce $1000 \mathrm{mg} / \mathrm{L} \mathrm{Mn}$ (II) stock solution. Biosorption batch experiments were conducted by adding $1.0 \mathrm{~g}$ of biosorbent into $50 \mathrm{~mL}$ of $\mathrm{Mn}$ (II) ions. Then, the mixture were shaken at a speed of $125 \mathrm{rpm}$ and temperature of $25 \pm 1^{\circ} \mathrm{C}$. The influences of $\mathrm{pH}(\mathrm{pH} 2$ to 7), contact time (1 to 90 minutes) and initial Mn(II) concentration (10 to $200 \mathrm{mg} / \mathrm{L}$ ) were investigated. The final effluents were filtered and analysed using Inductively Coupled Plasma Atomic Emission Spectroscopy (Perkin Elmer, 7300DV).

Biosorption Performance. The Mn(II) ions biosorption was calculated based on the following equation;

$$
\mathrm{Mn}(\mathrm{II}) \text { Biosorption (\%) }=\frac{\mathrm{C}_{\mathrm{o}}-\mathrm{C}_{\mathrm{f}}}{\mathrm{C}_{0}} \times 100 \%
$$

Where, $\mathrm{C}_{\mathrm{o}}$ is the initial $\mathrm{Mn}(\mathrm{II})$ ions concentration $(\mathrm{mg} / \mathrm{L}), \mathrm{C}_{\mathrm{f}}$ is the final $\mathrm{Mn}(\mathrm{II})$ ions concentration $(\mathrm{mg} / \mathrm{L})$. The sorption equilibrium of $\mathrm{Mn}(\mathrm{II})$ ions were determined by using the linearized Langmuir isotherm model.

$$
\frac{\mathrm{C}_{\mathrm{e}}}{\mathrm{q}_{\mathrm{a}}}=\frac{\mathrm{C}_{\mathrm{e}}}{\mathrm{q}_{\max }}+\frac{1}{\mathrm{bq}_{\max }}
$$

Where, $\mathrm{q}_{\mathrm{e}}$ is the $\mathrm{Mn}(\mathrm{II})$ ions uptake at equilibrium $(\mathrm{mg} / \mathrm{g}), \mathrm{q}_{\max }$ is the maximum biosorption capacity $(\mathrm{mg} / \mathrm{g}), \mathrm{C}_{\mathrm{e}}$ is the $\mathrm{Mn}(\mathrm{II})$ ions concentration at equilibrium $(\mathrm{mg} / \mathrm{L})$ and $\mathrm{b}$ is the Langmuir constant $(\mathrm{L} / \mathrm{mg})$. The kinetic data for $\mathrm{Mn}$ (II) ions biosorption were analysed using linearized pseudo-second order model.

$$
\frac{\mathrm{t}}{\mathrm{q}_{\mathrm{t}}}=\frac{1}{\mathrm{k}_{2} \mathrm{q}_{\mathrm{a}}^{2}}+\frac{1}{\mathrm{q}_{\mathrm{a}}} \mathrm{t}
$$

Where, $\mathrm{q}_{\mathrm{t}}$ is the $\mathrm{Mn}(\mathrm{II})$ ions uptake at time $(\mathrm{mg} / \mathrm{g}), \mathrm{t}$ is time (minute) and $\mathrm{k}_{2}$ is the rate constant of pseudo-second order $(\mathrm{g} / \mathrm{mg} / \mathrm{min})$.

\section{Results and Discussion}

Biosorption Studies. The effect of $\mathrm{pH}$ on the biosorption of $\mathrm{Mn}(\mathrm{II})$ ions by Pleurotus spent mushroom compost is presented in Fig.1. The contact time and initial Mn(II) concentration were held constant at 60 minutes and $50 \mathrm{mg} / \mathrm{L}$ respectively. The $\mathrm{Mn}$ (II) ions biosorption was increased from $4.8 \%$ to $49.3 \%$ with increasing $\mathrm{pH}$ values from $\mathrm{pH} 2$ to 7 . At low $\mathrm{pH}$, high $\mathrm{H}^{+}$concentration caused protonation of the biosorbent active binding sites. The charge repulsion occurred and thus, reduces $\mathrm{Mn}(\mathrm{II})$ ions biosorption $[15,16]$. As the $\mathrm{pH}$ increased, the biosorbent active binding sites were deprotonated and the charge attraction occurred between the active binding sites and Mn(II) ions. Therefore, the increase of $\mathrm{pH}$ value resulted in an increase of $\mathrm{Mn}$ (II) ions biosorption. The $\mathrm{Mn}$ (II) ions biosorption was rapidly increased as the $\mathrm{pH}$ values increased from 2 to 5 . However, no changes were observed between $\mathrm{pH} 5$ to 7 . Therefore, the subsequent experiments were conducted at $\mathrm{pH} 6$ because it is closer to the $\mathrm{Mn}(\mathrm{II})$ solution $\mathrm{pH}$ value. Similar $\mathrm{pH}$ trend also have been reported in $\mathrm{Mn}$ (II) ions biosorption study by Ma et.al [17].

The influence of contact time on the $\mathrm{Mn}$ (II) ions biosorption is presented in Fig. 2. The $\mathrm{pH}$ and initial $\mathrm{Mn}$ (II) concentration were held constant at $\mathrm{pH} 6$ and $50 \mathrm{mg} / \mathrm{L}$ respectively. The biosorption of $\mathrm{Mn}$ (II) ions rapidly occurred during the first 10 minutes of contact time, followed by an equilibrium phase after 20 minutes. The $\mathrm{Mn}$ (II) ions biosorption increased from $33 \%$ to $47 \%$ following the increase in contact time from 1 to 90 minutes. At the first phase (within 1 to 10 minutes), the biosorption process occurred rapidly because of large surface area and more biosorbent active binding 
sites were available for $\mathrm{Mn}$ (II) ions biosorption [15]. However, the biosorption process was slowed down and reach an equilibrium phase when the surface of the active binding sites were gradually occupied. Therefore, the further experiment was conducted at 20 minutes contact time.

The influence of initial Mn(II) concentration on the Mn(II) ions biosorption by Pleurotus spent mushroom compost is shown in Fig. 3. The $\mathrm{pH}$ and contact time were held constant at $\mathrm{pH} 6$ and 20 minutes respectively. The $\mathrm{Mn}$ (II) ions biosorption was reduced from $73 \%$ to $24 \%$ with increasing the initial $\mathrm{Mn}$ (II) concentrations from $10 \mathrm{mg} / \mathrm{L}$ to $200 \mathrm{mg} / \mathrm{L}$. This was due to at high concentrations, the number of active binding sites for biosorption process to occur is less compared to the number of $\mathrm{Mn}$ (II) ions present and thus reduced the $\mathrm{Mn}$ (II) ions biosorption. In addition, the initial concentration also provides a driving force to solve the mass transfer resistance in the $\mathrm{Mn}$ (II) ions biosorption [16].

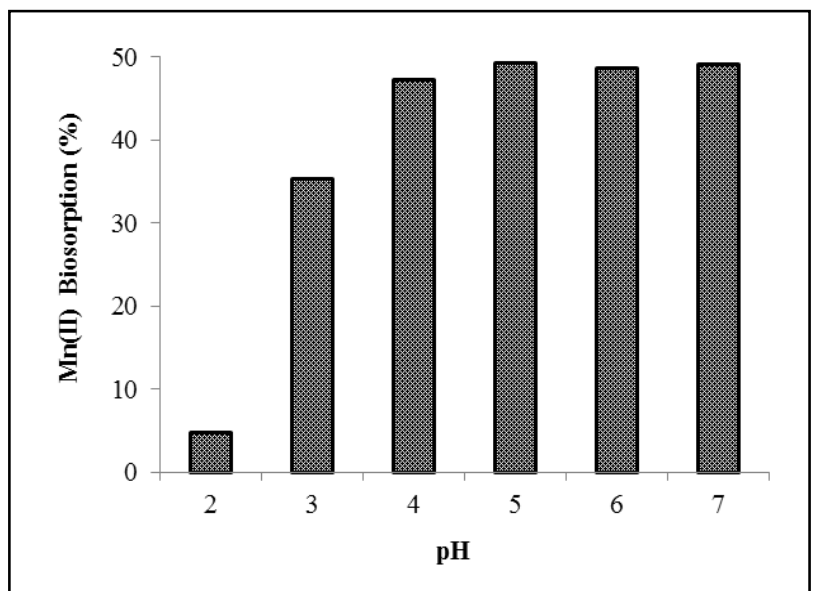

Fig. 1: Effect of $\mathrm{pH}$ on the $\mathrm{Mn}(\mathrm{II})$ ions biosorption (Mn(II) concentration: $50 \mathrm{mg} / \mathrm{L}$; biosorbent dosage: $1.0 \mathrm{~g}$; agitation speed: $125 \mathrm{rpm}$; temperature: $25^{\circ} \mathrm{C}$; contact time: 60 minutes)

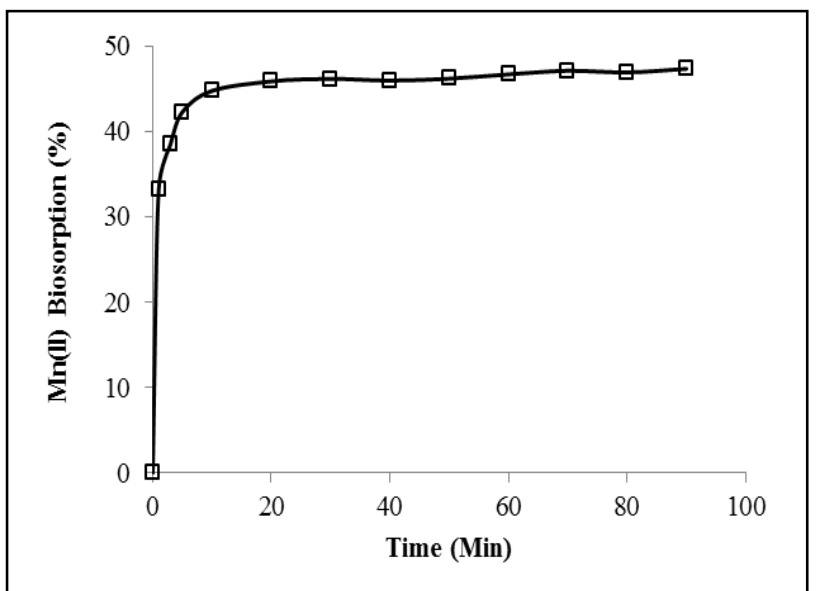

Fig. 2: Effect of contact time on the $\mathrm{Mn}(\mathrm{II})$ ions biosorption (Mn(II) concentration: $50 \mathrm{mg} / \mathrm{L} ; \mathrm{pH}: 6$; biosorbent dosage: $1.0 \mathrm{~g}$; agitation speed: $125 \mathrm{rpm}$; temperature: $25^{\circ} \mathrm{C}$ )

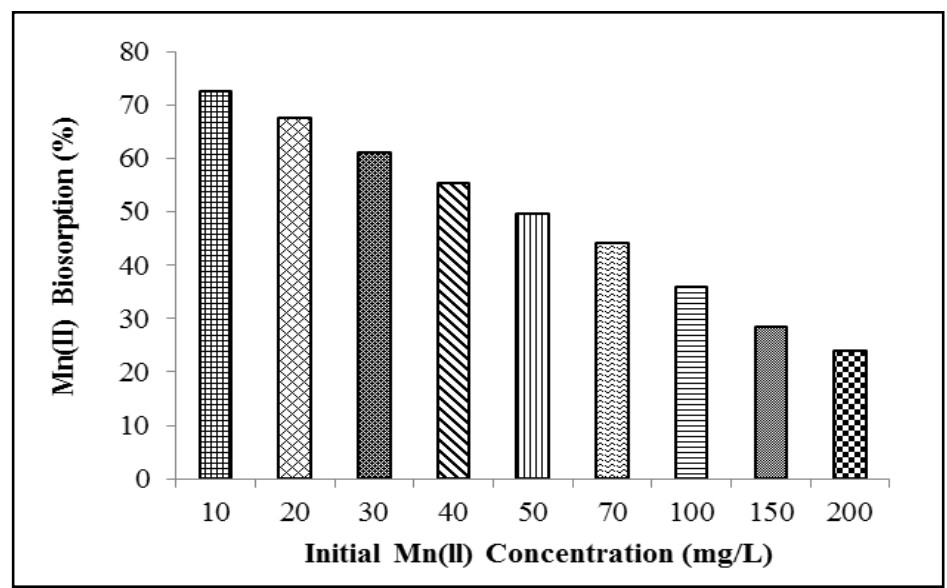

Fig. 3: The influence of initial $\mathrm{Mn}(\mathrm{II})$ concentration on the $\mathrm{Mn}(\mathrm{II})$ ions biosorption

(Biosorbent dosage: $1.0 \mathrm{~g}$; $\mathrm{pH}$ : 6; agitation speed: $125 \mathrm{rpm}$; temperature: $25^{\circ} \mathrm{C}$; contact time: 20 minutes)

Table 1: $\mathrm{R}_{\mathrm{L}}$ values at different initial $\mathrm{Mn}(\mathrm{II})$ concentration

\begin{tabular}{|c|c|c|c|c|c|c|c|c|c|}
\hline Conc. $[\mathbf{m g} / \mathbf{L}]$ & $\mathbf{1 0}$ & $\mathbf{2 0}$ & $\mathbf{3 0}$ & $\mathbf{4 0}$ & $\mathbf{5 0}$ & $\mathbf{7 0}$ & $\mathbf{1 0 0}$ & $\mathbf{1 5 0}$ & $\mathbf{2 0 0}$ \\
\hline $\mathbf{R}_{\mathbf{L}}$ & 0.6834 & 0.5191 & 0.4185 & 0.3505 & 0.3016 & 0.2357 & 0.1776 & 0.1258 & 0.0974 \\
\hline
\end{tabular}

Isotherm and Kinetic Study. Fig. 4 shows the Langmuir isotherm plot for Mn(II) ions biosorption onto Pleurotus spent mushroom compost. The values of $\mathrm{q}_{\max }, \mathrm{b}$ and $\mathrm{R}^{2}$ based on the plot of Langmuir isotherm model were $2.44 \mathrm{mg} / \mathrm{g}, 0.046 \mathrm{~L} / \mathrm{mg}$ and 0.9895 respectively. The dimensionless separation 
factor of equilibrium, $\mathrm{R}_{\mathrm{L}}$, which defined by Webi and Chakravort [18] was used to predict whether the biosorption system is favourable or unfavourable and the values are shown in Table 1 . The values of $\mathrm{R}_{\mathrm{L}}$, which was $0<\mathrm{R}_{\mathrm{L}}<1$ indicates that the biosorption was favourable at the conditions being studied. Fig. 5 shows the plot of pseudo-second order kinetic for $\mathrm{Mn}$ (II) ions biosorption onto Pleurotus spent mushroom compost. The values of $\mathrm{q}_{\mathrm{e}}, \mathrm{k}_{2}$ and $\mathrm{R}^{2}$ based on the plot of pseudo-second order kinetic model were $1.163 \mathrm{mg} / \mathrm{g}, 1.168 \mathrm{~g} / \mathrm{mg} / \mathrm{min}$ and 0.9999 respectively.

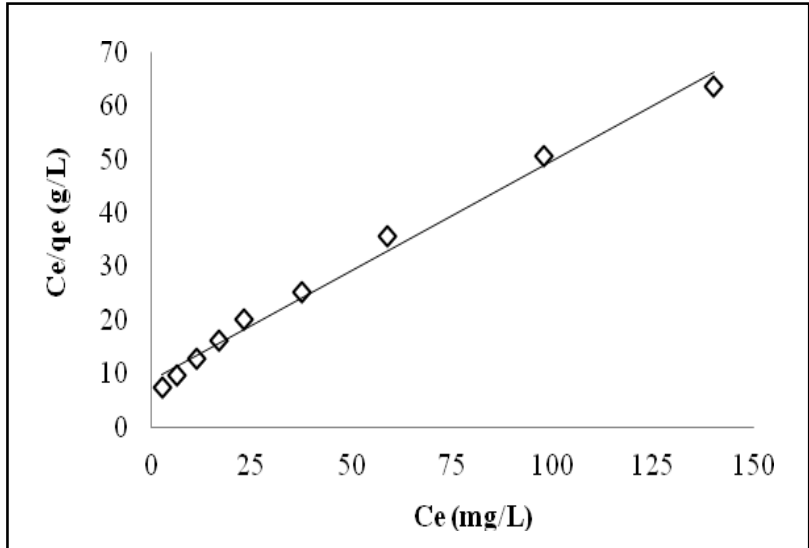

Fig. 4: Langmuir isotherm plot for $\mathrm{Mn}(\mathrm{II})$ ions biosorption onto Pleurotus spent mushroom compost

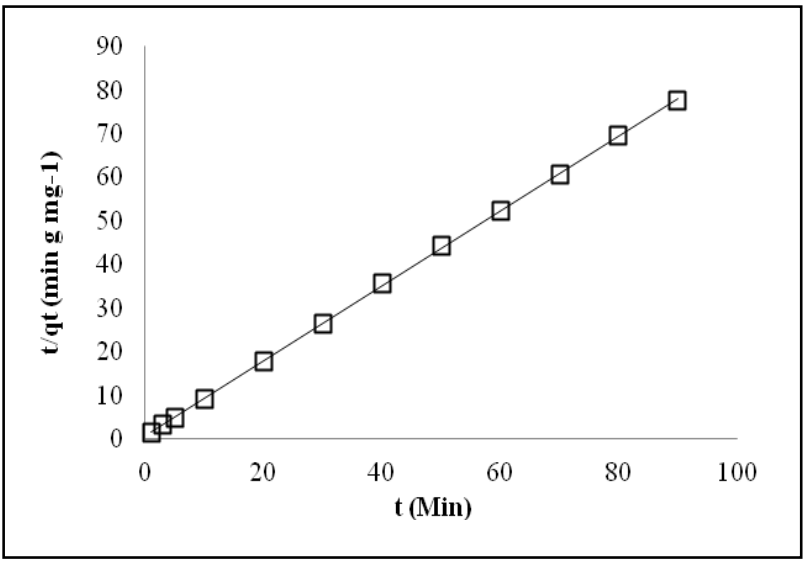

Fig. 5: Pseudo-second order kinetic plot for Mn(II) ions biosorption onto Pleurotus spent mushroom

\section{Conclusion}

The study demonstrates that the application of Pleurotus spent mushroom compost for $\mathrm{Mn}(\mathrm{II})$ ions biosorption. The performance of $\mathrm{Mn}$ (II) ions biosorption was strongly influenced by the $\mathrm{pH}$, contact time and the initial $\mathrm{Mn}$ (II) concentration. The $\mathrm{Mn}$ (II) ions biosorption were increased with increasing the $\mathrm{pH}$ value and contact time. Conversely, the $\mathrm{Mn}$ (II) ions biosorption shows a decreasing rate as the initial $\mathrm{Mn}$ (II) concentration increased. The $\mathrm{Mn}$ (II) ions biosorption were best described by the Langmuir isotherm model with a maximum biosorption capacity of $2.44 \mathrm{mg} / \mathrm{g}$ and the kinetic data follows a pseudo-second order kinetic model.

\section{Acknowledgements}

We are grateful for the university resources provided by Universiti Teknologi MARA, Malaysia. Special acknowledge to the Ministry of Education (MOE), Malaysia for granting us financial support under the Long Term Research Grant (LRGS) (203/PKT/6720004).

\section{References}

[1] Fu, F. \&Wang, Q (2011). Removal of heavy metal ions from wastewaters: A review. Journal of Environmental Management, 92: 407-418.

[2] Vijayaraghavan, K., \& Yun, Y.-S. (2008). Bacterial biosorbents and biosorption. Biotechnology Advances, 26(3), 266-91.

[3] Park, D., Yun, Y.S., and Park, J. M. (2010). The past, present, and future trends of biosorption. Biotechnology and Bioprocess Engineering, 15(1), 86-102.

[4] Gadd, G. M. (2009). Biosorption: critical review of scientific rationale, environmental importance and significance for pollution treatment. Journal of Chemical Technology and Biotechnology, 84(1), 13-28. 
[5] Han, R., Zhang, J., Zou, W., Xiao, H., Shi, J., \& Liu, H. (2006). Biosorption of copper ( II ) and lead ( II ) from aqueous solution by chaff in a fixed-bed column. Journal of Hazardous Materials, $133,262-268$.

[6] Amarasinghe, B. M. W. P. K., \& Williams, R. A. (2007). Tea waste as a low cost adsorbent for the removal of $\mathrm{Cu}$ and $\mathrm{Pb}$ from wastewater. Chemical Engineering Journal, 132, 299-309.

[7] Krishnani, K. K., Meng, X., Christodoulatos, C., \& Boddu, V. M. (2008). Biosorption mechanism of nine different heavy metals onto biomatrix from rice husk. Journal of Hazardous Materials, 153, 1222-1234.

[8] Witek-krowiak, A., Szafran, R. G., \& Modelski, S. (2011). Biosorption of heavy metals from aqueous solutions onto peanut shell as a low-cost biosorbent. DES, 265(1-3), 126-134. doi:10.1016/j.desal.2010.07.042

[9] Lugo-lugo, V., Barrera-díaz, C., Ureña-núñez, F., Bilyeu, B., \& Linares-hernández, I. (2012). Biosorption of $\mathrm{Cr}$ ( III ) and Fe ( III ) in single and binary systems onto pretreated orange peel. Journal of Environmental Management, 112, 120-127.

[10] García-mendieta, A., Olguín, M. T., \& Solache-ríos, M. (2012). Biosorption properties of green tomato husk ( Physalis philadelphica Lam ) for iron, manganese and iron - manganese from aqueous systems. Desalination, 284, 167-174.

[11]Zakaria, Z. A., Suratman, M., Mohammed, N., \& Ahmad, W. A. (2009). Chromium (VI) removal from aqueous solution by untreated rubber wood sawdust. DES, 244(1-3), 109-121.

[12]Vinodhini, V., \& Das, N. (2010). Packed bed column studies on Cr (VI) removal from tannery wastewater by neem sawdust. Desalination, 264(1-2), 9-14.

[13]Volesky, B. (2007). Biosorption and me. Water Research, 41(18), 4017-29.

[14]Singh, A. D., Noorlidah, A. and Vikineswary, S. (2003). Optimization of extraction of bulk enzymes from spent mushroom compost. Journal of Chemical Technology and Biotechnology, 78: 743-752.

[15]Khosravihaftkhany, S., Morad, N., Teng, T. T., Abdullah, A. Z., \& Norli, I. (2013). Biosorption of $\mathrm{Pb}$ (II) and $\mathrm{Fe}(\mathrm{III})$ from Aqueous Solutions Using Oil Palm Biomasses as Adsorbents. Water, Air, \& Soil Pollution, 224(3), 1455.

[16]Tay, C.-C., Liew, H.-H., Redzwan, G., Yong, S.-K., Surif, S., \& Abdul-Talib, S. (2011). Pleurotus ostreatus spent mushroom compost as green biosorbent for nickel (II) biosorption. Water Science \& Technology, 64(12), 2425-2432.

[17]Ma, L., Peng, Y., Wu, B., Lei, D., \& Xu, H. (2013). Pleurotus ostreatus nanoparticles as a new nano-biosorbent for removal of $\mathrm{Mn}(\mathrm{II})$ from aqueous solution. Chemical Engineering Journal, $225,59-67$.

[18]Webi, T.W. \& Chakravort, R.K. (1974). Pore and solid diffusion models for fixed-bed adsorbers, AIChE J. 20 228-238. 